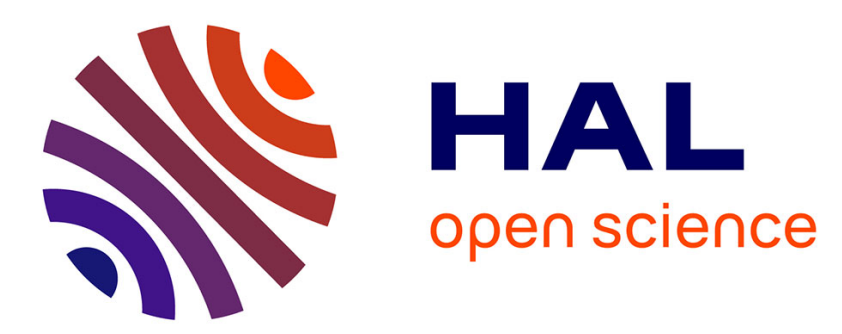

\title{
Ecological and physiological effects of soil management practices on earthworm communities in French vineyards
}

Eva Schreck, Laure Gontier, Camille Dumat, Florence Geret

\section{To cite this version:}

Eva Schreck, Laure Gontier, Camille Dumat, Florence Geret. Ecological and physiological effects of soil management practices on earthworm communities in French vineyards. European Journal of Soil Biology, 2012, vol. 52, pp. 8-15. 10.1016/j.ejsobi.2012.05.002 . hal-00815310

\author{
HAL Id: hal-00815310 \\ https://hal.science/hal-00815310
}

Submitted on 18 Apr 2013

HAL is a multi-disciplinary open access archive for the deposit and dissemination of scientific research documents, whether they are published or not. The documents may come from teaching and research institutions in France or abroad, or from public or private research centers.
L'archive ouverte pluridisciplinaire HAL, est destinée au dépôt et à la diffusion de documents scientifiques de niveau recherche, publiés ou non, émanant des établissements d'enseignement et de recherche français ou étrangers, des laboratoires publics ou privés. 


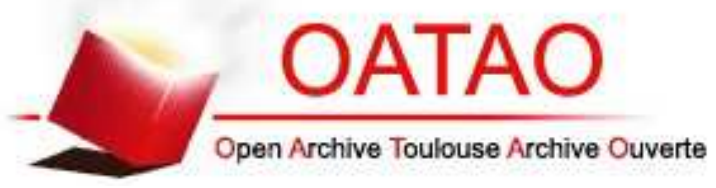

\section{Open Archive Toulouse Archive Ouverte (OATAO)}

OATAO is an open access repository that collects the work of Toulouse researchers and makes it freely available over the web where possible.

This is an author-deposited version published in: http://oatao.univ-toulouse.fr/ Eprints ID: 6551

To link to this article: DOI:10.1016/j.ejsobi.2012.05.002 URL: http://dx.doi.org/10.1016/j.ejsobi.2012.05.002

To cite this version: Schreck, Eva and Gontier, Laure and Dumat, Camille and Geret, Florence Ecological and physiological effects of soil management practices on earthworm communities in French vineyards. (2012) European Journal of Soil Biology, vol. 52 . pp. 8-15. ISSN 11645563

Any correspondence concerning this service should be sent to the repository administrator: staff-oatao@ listes.diff.inp-toulouse.fr 


\title{
Ecological and physiological effects of soil management practices on earthworm communities in French vineyards
}

\author{
Eva Schreck ${ }^{\mathrm{a}, \mathrm{b}, \mathrm{c}, *}$, Laure Gontier $^{\mathrm{a}}$, Camille Dumat $^{\mathrm{b}, \mathrm{c}}$, Florence Geret $^{\mathrm{d}}$ \\ a Institut Français de la Vigne et du Vin (IFV France) - Pôle Sud-Ouest, V'innopôle, BP 22, 81310 Lisle sur Tarn, France \\ ${ }^{\mathrm{b}}$ Université de Toulouse, INP-ENSAT, Avenue de l'Agrobiopôle, 31326 Castanet-Tolosan, France \\ ' UMR 5245 CNRS-INP-UPS, EcoLab (Laboratoire Ecologie fonctionnelle et Environnement), Avenue de l'Agrobiopôle, BP 32607,31326 Castanet-Tolosan, France \\ ${ }^{\mathrm{d}}$ UMR CNRS 5602, Laboratoire GEODE, PRES Université de Toulouse, Centre Universitaire Jean-François Champollion, Place de Verdun, 81012 Albi cedex 9 , France
}

Keywords:

Earthworms

Vineyard

Weeding practices

Ecology

Ecotoxicity

Biomarkers

\begin{abstract}
A B S T R A C T
In recent literature, very few studies have reported the use of the combination of indicators from ecological communities and ecotoxicity biomarkers in field experiments to assess agricultural quality. Therefore, the aim of this study was to determine the influence of three soil management practices of vine inter-rows (chemical weeding, mechanical weeding and grass-covering) on earthworms, in the Gaillac vineyard (South-West France). The sampling, identification and counts of earthworms were performed in spring and autumn over three years in order to determine the influence of the management practices. Focussing on the most abundant species, Aporrectodea nocturna, biomarker assays (glutathione-S-transferase (GST), catalase (CAT) and cholinesterase (ChE) activities) were conducted to check physiological disturbances that are indirectly linked to soil management practices.

A strong influence of soil management practices was highlighted on earthworm ecology and physiology in the vine inter-rows. Chemical weeding favoured worm proliferation, but proportionally decreased the number of epi-anecic species. Mechanical weeding dramatically decreased the total number of earthworms, both adults and juveniles, and their biomass. Under these soil farming practices, variations of metabolisation and anti-oxidant enzyme activities were observed, suggesting an increase in pesticide bioavailability. Grass-covering seemed to be the best practice, at least from an environmental point of view. Neurotoxicity enzyme (cholinesterase) activity in vineyard earthworms was not affected by pollutants conventionally sprayed on the vineyard, regardless of soil agricultural practice.

It was concluded that soil management practices can both modify earthworm communities and physiology, inducing variations of the following factors: protection against predators, environmental conditions and availability of pesticide and nutrients.
\end{abstract}

\section{Introduction}

In French vineyards, weed control is an agricultural imperative for high quality production and grape yields. Environmental concerns, regarding the ecological impacts of herbicide use, have focused on the chemical pollution of soil, surface and underground water, and organisms living in the vineyard ecosystem [1]. Thus, alternative management strategies to chemical weeding, such as grass-cover systems or mechanical weeding, which involves conservation tillage and loosening at $15 \mathrm{~cm}$ depths, were implemented several years ago in vine-growing areas in order to reduce

\footnotetext{
* Corresponding author. UMR 5245 CNRS-INP-UPS, EcoLab (Laboratoire Ecologie fonctionnelle et Environnement), Avenue de l'Agrobiopôle, BP 32607, 31326 Castanet-Tolosan, France. Tel.: +33 534323900

E-mail address: eva.schreck@ensat.fr (E. Schreck).
}

herbicide spraying. However, even though these alternative soil management practices limit the use of herbicides, insecticides and fungicides are still largely sprayed on the vines to control organisms considered as pests for vineyards [2]. In addition, these compounds can easily transfer to soil horizons, impacting on living organisms. Furthermore, soil management practices in vineyards may change soil parameters, such as structure, aeration, humidity, water infiltration, pesticide mobility and the transfer to sub-surface water, as well as the bioavailability of these pollutants to soil organisms $[3,4]$.

An understanding of the influence of agricultural management on soil ecosystems is necessary for the development of sustainable viticulture [5], since it is generally accepted that soil is a living and non-renewable resource that is highly sensitive to climate changes or human activities, including farming practices, crop type, tillage and the use of chemical compounds [6,7]. 
Generally, in contrast to chemically weeded soils, grassed zones are reported to provide a great source of organic matter, and protection against predators for living organisms in agricultural soils, and they also limit pesticide transfer to surface waters in vineyards [4]. By contrast, as reported by Düring et al. [8], several soil tillage applications could be responsible for pollutant enrichment. Soil aggregates are actually broken by the increase of nutrient and pollutant bioavailability caused by tillage [8]. Hendrix et al. [9] and Lavelle et al. [10] reported that soil cultivation influences the activity of different communities, especially those of earthworms.

Indeed, earthworms play a key role in soil biology [11]: they impact soil structure through their decomposition activities, nutrient mineralisation and bioturbation, also known as burrowing and casting. They are naturally in contact with the solid, aqueous and gaseous soil phases and, as a result, are directly exposed to contaminants. For this reason, they can be studied as good indicators of the impact of soil management practice on ecology and ecotoxicity in vineyards.

From an ecological point of view, the composition of earthworm communities is a potential measurement endpoint for the biological assessment of soil quality using ecological categories, according to Bouché [12] and Sims and Gerard [13], rather than earthworm numbers $[11,14]$. The impact of earthworms on soil properties and quality differ according to their species or functional groups [15]. Anecic species that are detritivorous, can enhance the turnover of organic residues and microbial activity. Therefore, they also contribute to an enhanced mineralisation and nutrient availability in soil [16]. Endogeic and anecic burrowing and feeding activities modify soil structure.

From an ecotoxicity point of view, earthworms are likely to be sensitive to tillage, inputs of organic matter and the application of chemicals [17,18]. Several studies reported that insecticides and fungicides highly impact neurotransmission enzyme activity (cholinesterase: $\mathrm{ChE}$ ) or metabolisation enzyme activities such as glutathione-S-transferase (GST) or catalase (CAT), in studies primarily using micro- or mesocosms [19-22]. These enzymes were successfully used by Ribera et al. [23] on Eisenia fetida and by Schreck et al. [24] on Aporrectodea nocturna in laboratory experiments checking the impact of pesticides on earthworms. The cholinesterase enzyme, acting by hydrolysis of the neurotransmitter acetylcholine at the synapses, was used as an earthworm neurotoxicity biomarker $[19,20,25]$. The enzyme glutathione-Stransferase, which attaches a polar compound to toxic molecules during the metabolisation process, promoting their elimination by excretion, and the anti-oxidant enzyme catalase, which works on reactive oxygen species, were both used to determine disruptions due to pesticides $[23,24]$. These enzymes have already been shown to give good responses to environmental disturbances for $E$. fetida and Lumbricus rubellus in previous studies $[21,22,26]$.

Recently, in addition to ecological studies [27], biochemical biomarkers have been used in some field experiments to assess the physiological disturbances on earthworms due to pollutant exposure $[28,29]$. However, the indirect impact of farming practices, such as protection against predators, environmental conditions and the availability of pesticide and nutriments, on earthworm physiology in field conditions was still poorly described [30], especially in the vineyards.

As a result, the aim of this study was to evaluate the ecological and physiological effects of three different soil management practices (chemical weeding, mechanical weeding and grass-covering) on earthworms, using both ecological indicators and biochemical biomarkers. Whereas several studies were performed in laboratory conditions and on E. fetida [31], this article focused on a field study, performed on endemic soil dwelling species i.e. A. nocturna, as suggested by Nahmani et al. [32]. The use of this original combination of ecology and ecotoxicity parameters in a real experimental vine-growing area in the Gaillac vineyard in the South-West of France allows for a better understanding of the global impact of soil management practices on vineyard soil qualities.

\section{Materials and methods}

\subsection{The experimental site}

The approximately 4 ha study area is located in a Gaillac vineyard in the South-West France, about $60 \mathrm{~km}$ from Toulouse $\left(43^{\circ} 50^{\prime} 26.88^{\prime \prime} \mathrm{N}-1^{\circ} 50^{\prime} 59.56^{\prime \prime} \mathrm{E}\right)$. The region has the typical soil from the Mid-Pyrenees region, redoxi-luvisols, described by the International Society of Soil Science (ISSS) and the Food and Agriculture Organisation of the United Nations [33], and locally known as "Boulbènes". This soil type contains quaternary alluvial deposits from the rivers of South-West France. A great textural differentiation in the profile shows that surface horizon clay has been depleted and clay has accumulated in a $0.6 \mathrm{~m}$ deep argic horizon [34]. Mainly formed by illuviation, the argic horizon is compact and has a low internal permeability. As a result, water stagnates in the upper horizon during the winter, while the soils are actually dry in summer [34]. The soil of the study has a $\mathrm{pH}$ of 6.7 and its organic carbon content is $1 \%$.

Each year, insecticides (chlorpyrifos-ethyl, $\lambda$-cyhalothrin) and fungicides (folpet, metalaxyl-M, fosetyl-Al and myclobutanil), including copper and sulphur, were sprayed between May and July as a conventional protection of the vines against pests.

In 2005, for this study, the experimental site was divided into three plots ( 1 ha each) that were managed according to the different soil agricultural practices, generally used in the Mid-Pyrenees [35]. The first vine plot was chemically weeded in the inter-rows. The second had mechanically weeded inter-rows (conservation tillage, $15 \mathrm{~cm}$ deep loosening with a superficial tillage tool called the Actisol $^{\circledR}$ ), and the final plot was grass-covered (50\% Festuca arundinacea, 30\% Lolium perenne and 20\% Festuca rubra).

A 1 ha grass-covered area, without any vine-growing or any pesticide treatment, on the same luvisol-reduxisol soil near the experimental site was used as a control.

\subsection{Earthworm sampling and counting}

The investigations began one year after experimental area was established (in 2006).

Two kinds of sampling were employed as follows:

Method 1-The earthworm communities were randomly sampled in the spring and autumn of 2006 and 2007, and again in the spring of 2008 and 2009. These two seasons were chosen as the average temperatures and humidity are optimal for earthworm activity [36]. Within each different soil management plot, ten subsample quadrants of $0.25 \mathrm{~m}^{2}$, at a depth of $30 \mathrm{~cm}$, were made in the inter-rows [37]. Earthworms were removed from each sub-sample by hand sorting (manual screening), as described by Pelosi et al. [38]. No expellants were used prior to hand sorting to ensure that there were no adverse effects on earthworm physiology and, therefore, no perturbations of enzyme activities. Sampled earthworms were placed into labelled plastic containers containing wet soil with perforated lids, out of direct sunlight. After rinsing with cold water, counts, biomass measures and identifications were performed in the laboratory. Earthworms were then classified into three ecotypes as described by Bouché [12] and Sims and Gerard [13]: the epi-anecics, the anecics and the endogeics. As reported by Pérez-Losada et al. [39] and Briones et al. [40], the taxonomic status of several species is often debated and remains complex, and is 
especially true for Aporrectodea caliginosa species. In order to avoid any taxonomic confusion, the species determination was performed according to recent classifications [39], and earthworms were described with the authority names as references.

Method 2-Three more samplings were performed in the spring, summer and autumn in order to study biomarker responses throughout the pesticide treatment period. These three sampling dates were chosen according to pesticide application kinetics. The spring season corresponds to the start of the fungicide applications; the summer is the period of fungicide spraying and the beginning of insecticide treatments; and the autumn sampling occurs three months after the last pesticide treatments. Three sub-samples were made per area. The earthworms were collected using the same sampling methodology as for the community density study, and the species were then identified. After a fasting period of three days for gut content excretion [22], the earthworms were rinsed in water, dried and stored at $-80^{\circ} \mathrm{C}$ until biomarker analysis.

\subsection{Biomarker assays}

Biomarker assays were performed on specimens of the earthworm A. nocturna using as suggested by Pérez-Losada [39], because it was the most abundant earthworm species in the vineyard. Enzyme-specific activities vary according to species [41], and A. nocturna was chosen because its biomarker responses to pesticide exposure have previously been studied in a number of laboratories [20,24], and also because of its high population density in the experimental area.

The first step of biochemical analysis was performed by individually homogenising each earthworm $\left(12000 \mathrm{rpm}, 4{ }^{\circ} \mathrm{C}\right)$ in a combined TRIS-buffer (50 mM pH 7.2, $0.15 \mathrm{M} \mathrm{NaCl}, 0.3 \mathrm{M}$ sucrose, $1 \mathrm{mM}$ EDTA, $0.02 \mathrm{M} \mathrm{NaH}_{2} \mathrm{PO}_{4}, 0.1 \%$ triton X100) in a $1: 3 \mathrm{w} / \mathrm{v}$ ratio, using a Polytron PT 1300D homogeniser from Kinematica [24]. This buffer allowed for the quantitative determination of all three enzyme activities from one invertebrate homogenate, which was separated into three fractions and one was used for each enzyme [42]. In the GST fraction, dithiothreitol was added (100 mM), in a $1: 100 \mathrm{v} / \mathrm{v}$ ratio. In the CAT fraction, Triton X100 $(0.4 \%)$ was added followed by sonication for $10 \mathrm{~min}$. The homogenates were then centrifuged at $9000 \times \mathrm{g}$ for $25 \mathrm{~min}$ at $4{ }^{\circ} \mathrm{C}$.

$\mathrm{ChE}$ activity was measured using the method described by Ellman et al. [43], with modifications for detection in earthworms [36]. Acetylthiocholine iodide was used as a substrate and 5,5'dithiobis (2-nitrobenzoic) acid (DTNB) was used as a chromogen. The activity was studied spectrophotometrically (Jenway $6505)$ at $412 \mathrm{~nm}$.

Glutathione-S-transferase activity was measured using the method described by Habig et al. [44], with 1-chloro-2,4-dinitrobenzene $(\mathrm{CDNB})$ as a substrate for spectrophotometrical measurement at $340 \mathrm{~nm}$ and $37^{\circ} \mathrm{C}$.

Catalase activity was determined by measuring the production of hydrogen peroxide at $240 \mathrm{~nm}$. As reported by Saint-Denis et al. [26], catalase activity increased with $\mathrm{H}_{2} \mathrm{O}_{2}$ concentration in the solution.

Total protein contents were determined using the Bradford method [45]. Enzyme activities were expressed as nmol min ${ }^{-1} \mathrm{mg}^{-1}$ of proteins.

Glutathione-S-transferase and catalase enzymes are both involved in the biotransformation process, so their activity variations were analysed collectively.

\subsection{Statistics}

As described in 2.2 and 2.3, the replication of treatments was achieved by sub-sampling in each plot many times, according to the season. However, sub-samples are neither true nor independent, as they occur in the same plot. For earthworm densities, biomasses and their biochemical responses, samples on consecutive dates are likely to be correlated and non-independent. Therefore, repeated measures two-way analysis of variance (ANOVA) and Tukey's posthoc tests were performed with sampling date as the repeated measures effect. The homogeneity of variances was tested using Levene's test. Analysis of ecological group distribution according to the soil management practice used was conducted using a one-way ANOVA on earthworms from spring samples, followed by Tukey's separation test. If the dependent variables were not homogeneous even after logarithmic transformation, non-parametric Kruskal-Wallis and Dunn tests were used instead of ANOVA.

The probability level for statistical significance was $P<0.05$. All of the analyses were performed using the XLSTAT ${ }^{\circledR}$ software, and all values are presented as mean $\pm \mathrm{SD}$.

Furthermore, the impact of soil management on the earthworm ecological categories according to the last two sampling dates (spring 2008 and spring 2009) was determined by a multivariate analysis. It was based on Principal Component Analysis (PCA) and allowed for good screening. It was performed with The Unscrambler $^{\circledR}$ software (version 9.8) edited by CAMO in order to extract the main sources of variance in the data sets. The 30 samples (10 replicates from the 3 agricultural practices) were projected on the Principal Component axes, and computed as a linear combination of the 6 original variables (i.e. the number of the ecological groups for each year). The Principal Components (PC) are built to capture the widest variance of the dataset, and are sorted in a descending manner with regard to the explained variance percentage. As they are all orthogonal, the information explained and visualised for each PC is different, and therefore complementary.

\section{Results}

\subsection{Earthworm communities}

Five species were identified from the experimental area. The most common anecic species were A. nocturna (described by PérezLosada et al. [39]) and Nicodrilus caliginosus meridionalis (described by Bouché [12]), and the most frequently observed epi-anecic species was Lumbricus friendi (determined by Cognetti [46] and Bouché [12]). Among endogeic earthworms, three species were identified: a few Allolobophora chlorotica (Savigny, 1826) and Octolasium cyaneum (Savigny, 1826) individuals were seen, alongside numerous examples of a pink endogeic species, which were impossible to determine since all individuals were juveniles without clitellums.

Fig. 1 gives an overall picture of the variation in the mean earthworm densities (adults and juveniles) between spring 2006 and spring 2009, according to the soil agricultural practice applied. Earthworm abundance varied across the experimental practices and with sampling season (ANOVA Tukey's test, $P<0.05$ ). Mean earthworm abundances varied between $26 \pm 13$ earthworms per square metre for mechanical weeding in autumn 2007 and $241 \pm 31$ earthworms per square metre for chemical weeding in spring 2009.

As demonstrated by Fig. 1, the earthworm community was generally dominated by juveniles, regardless of the soil management practice or the sampling season. Seasonal variations and changes in species diversity were clearly observed for each soil management practice over the three-year study period. The area that was chemically weeded showed the highest earthworm density during the entire study period, and differed significantly $(P<0.05)$ from all other treatments, practices and control during autumn 2006. Under mechanical weeding, earthworm abundance 


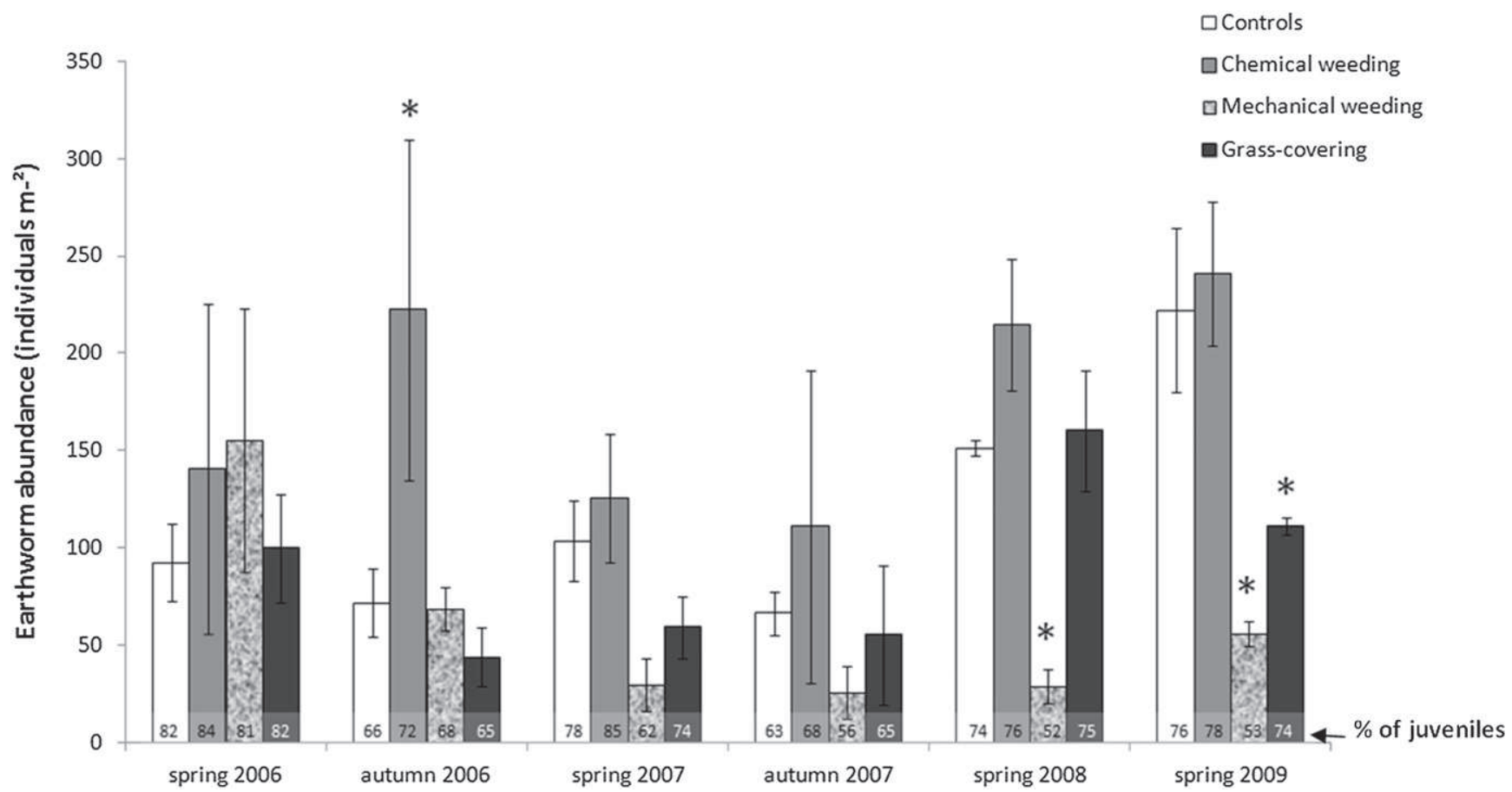

Fig. 1. Total earthworm abundance (adults + juveniles), reported as mean values (total abundance $\pm S D, n=10$ ) in the vine inter-rows under the different soil management practices for different sampling dates (spring 2006, autumn 2006, spring 2007, autumn 2007, spring 2008 and spring 2009 - Gaillac vineyard, South-West France). The percentage of juveniles is annotated for each modality as a number in the bottom of the bar. For each sampling date, the agricultural practice(s) with starred *data are significantly different to the controls at $P<0.05$ (repeated measures two-day ANOVA).

tended to decrease, with the mean being significantly different from those of the other plots in the spring samples from 2008 to 2009 $(P<0.05$, ANOVAs, Tukey's test $)$ and proportionally, the number of juveniles decrease over the time suggesting a disturbance in reproduction function. The abundance in the grass-covered interrows generally progressed in a similar manner to that of the control zone, as there were no significant differences between the two plots except for the last sample set from spring 2009.

Concerning earthworm weight, a significant decrease in mean adult biomass was observed under mechanical weeding from autumn 2007 to the end of the experiment, in comparison to the other management practices (results not shown, ANOVA, $P<0.05$ ).

The PCA results are shown in Fig. 2. Three sample groups could be extracted from PCA (Fig. 2) according to the soil management practice. PC 3 was mainly explained by the epi-anecics for the 2 years (G1-2008 and G1-2009, Fig. 2). Samples from the grasscovering (M3) also showed a high number of epi-anecics. Chemical weeding (M1) was discriminated by the anecic and endogeic earthworms, whereas epi-anecics were less well represented. Data from mechanical weeding (M2, Fig. 2) showed that this practice involved low numbers of individuals for each ecological category, but especially for the anecic and endogeic invertebrates.

To avoid the bias due to different community densities, the proportion of each ecological category according to soil management practice was recorded in the spring period, when earthworms are numerous and sampling is easy to perform. The data used for this ecological classification were mean values of replicates $(n=10)$ over the last two spring samples (2008 and 2009), and were expressed as a percentage for each agricultural practice (results not shown). Taken as a whole, the epi-anecics are the least represented earthworms, comprising about $20 \%$ of the total number of earthworms. There is a clear impact of soil agricultural practice on the densities of endogeic and epi-anecic communities (results not shown; epianecics analysed by Kruskall-Wallis, $P<0.01$; anecics analysed by ANOVA, $P>0.05$; endogeics analysed by Kruskall-Wallis, $P<0.05$ ).
Under chemical weeding, the epi-anecic proportional density (with Lumbricus as the main genus) was lower than in the grass-covered plots (vineyard and controls; Kruskall-Wallis, Dunn test, $P<0.01$ ). Mechanical weeding had an impact on the distribution of ecological categories as there were proportionally less epi-anecic and endogeic earthworms than with the other soil management practices (Kruskall-Wallis, Dunn test, $P<0.05$ ). The grass-covered vineyard area showed no significant differences from the grasscovered control zone in terms of ecological community distribution. The densities of anecic earthworms were not influenced by any of the soil management practices applied in the vine inter-rows (ANOVA, $P>0.05$ ).

\subsection{Biochemical responses}

Results of specific GST (A) and CAT (B) activities according to soil management practice applied in the vine inter-rows for the three sampling periods are shown in Fig. 3. According to ANOVA Tukey's test, the activities of these two biotransformation enzymes were modified, by either enhancement or inhibition, as a function of the applied soil management.

In the spring and summer, only activation of the CAT activity (Fig. 3B) occurred for earthworms in regions undergoing chemical and mechanical weeding, compared to grass-covered areas (ANOVA, Tukey's post-hoc test, $P>0.05$ ). For the other sampling dates, there were no significant differences in the 2 enzyme activities between the differently managed plots, i.e. the activity levels were similar to the pesticide free controls from the grass-covered zone (Fig. 3). In October, three months after the final treatments, GST and CAT activities were partially inhibited in the earthworms from the chemically and mechanically weeded plots in comparison to the earthworms from the control area which did not receive pesticide applications (ANOVA, Tukey's post-hoc test, $P<0.05$ ).

Fig. 4 shows that ChE activity was not influenced by soil management (ANOVA with Tukey's post-hoc test, $P>0.05$ ), as no 


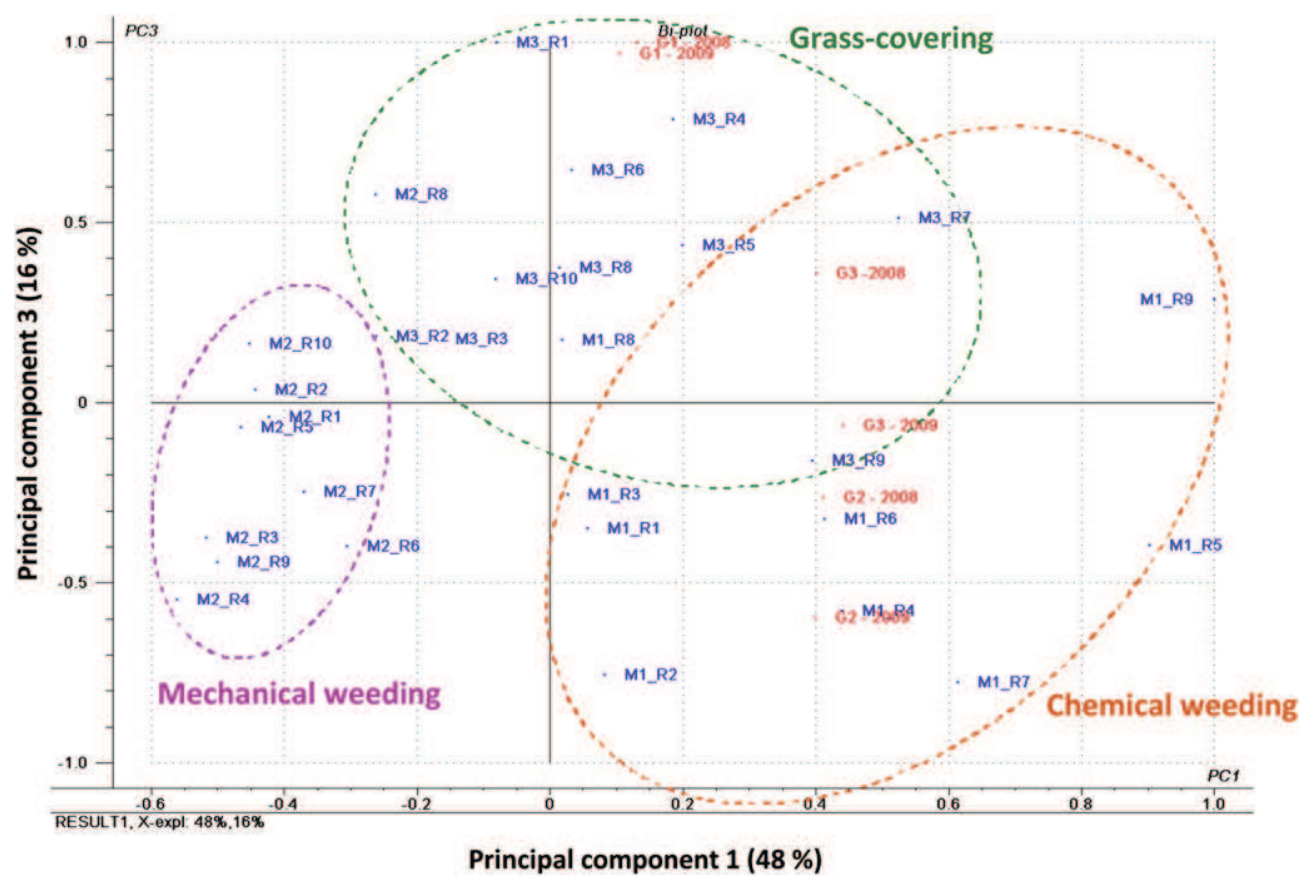

Fig. 2. Principal Component 1 vs 3 (PCA), discriminating the earthworm communities (G1: epi-anecics, G2: anecics, G3: endogeics) and sampling dates (2008 and 2009) for the replicates $(\mathrm{R}, n=10)$ of the three soil agricultural practices (M1: chemical weeding, M2: mechanical weeding, M3: grass-covering).

significant difference was found between the activities of the earthworms sampled from the differently managed plots or on different sampling dates.

\section{Discussion}

\subsection{Impact of soil management practices on earthworm ecology}

A significant influence was observed on the total number of earthworms and their individual biomass, the percentage of juveniles and the composition of each community, depending on the soil management practices used. In the following paragraph, mechanisms potentially involved to explain these effects are discussed.

The abundance and individual biomass of earthworms in the present study were comparable to those reported in earlier studies of agricultural soils $[47,48]$. The seasonal variations observed in the number of earthworms sampled from each plot correlated to the soil characteristics [7]. In spring 2006, no significant difference in terms of worm numbers was observed between the different plots, but the experiment had only been set up for a year and soil management practices may not have had any impact yet. By contrast, in 2009, climatic conditions (rainfall) at the study site had provided favourable conditions for earthworm proliferation.

According to Knight and Dick [49], soil management practices could be responsible, at least partly, for soil quality and the subsequent earthworm proliferation. From autumn 2006 to 2009, the earthworms were generally more numerous under chemical weeding than under the other practices. Similar observations have previously been reported for benomyl fungicide exposure by Christensen and Mather [50] and for glyphosate herbicide exposure by Santos [51]. Chemical weeding at the start of spring could have brought a new source of nutrients, such as organic matter from weed destruction, which promotes lumbricid proliferation, emergence and migration following herbicide spraying and then enhances the turnover in earthworm communities. Indeed, Pérès et al. [52] have shown that organic matter increased abundance and

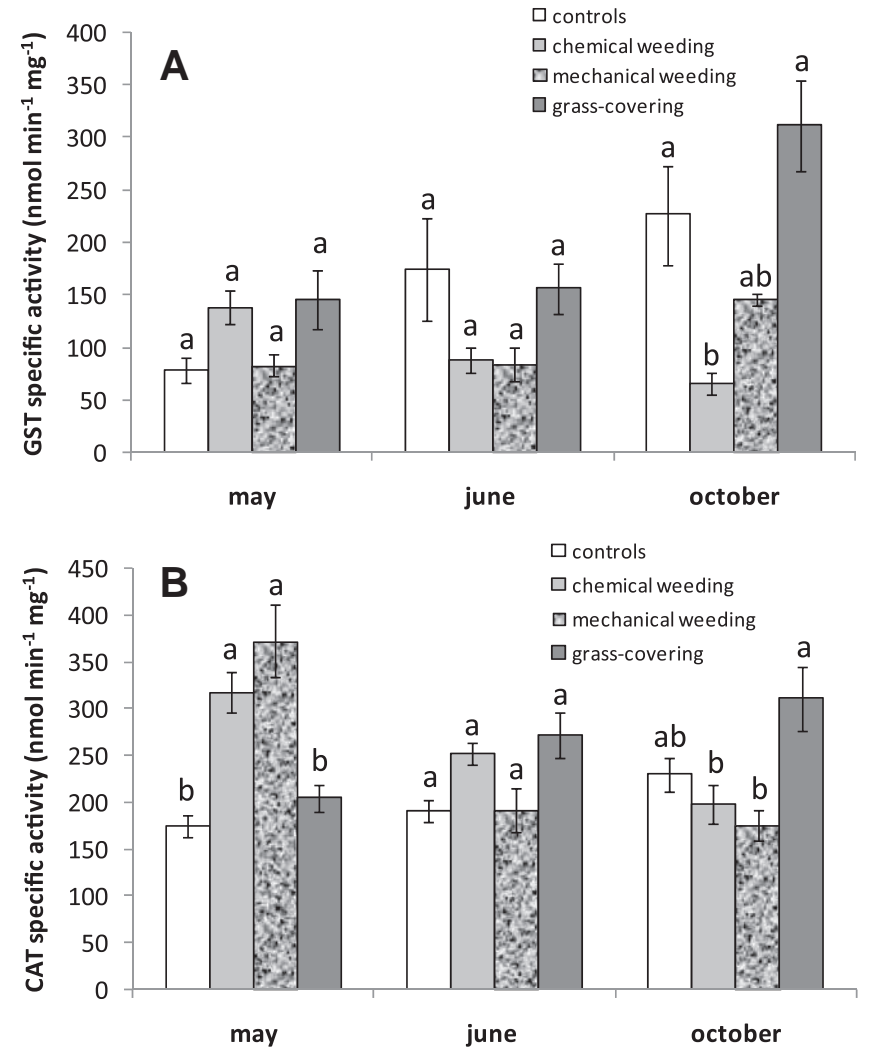

Fig. 3. Glutathione-S-transferase (A) and catalase (B) specific activities of the earthworm A. nocturna collected at 3 sampling dates under different soil managements, in the Gaillac vineyard, South-West France. Bars are the mean activities of the individuals in the different plots $( \pm$ SD). Different letters indicate significant differences between agricultural practices for each sampling date, $P<0.05$ (ANOVA with Tukey's post-hoc test). 


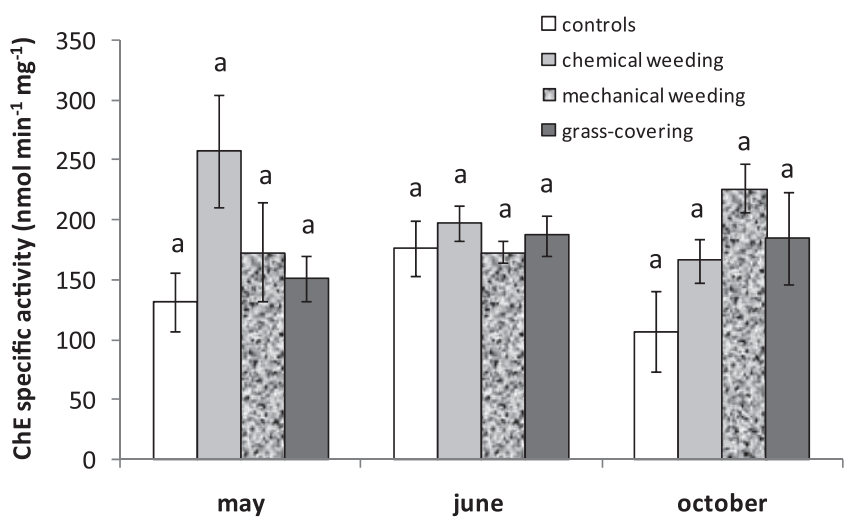

Fig. 4. Cholinesterase specific activity of the earthworm A. nocturna collected at 3 sampling dates under different soil managements, in the Gaillac vineyard, South-West France. Bars are the ChE mean activities of the individuals in the different plots $( \pm S D)$. Different letters indicate significant differences between agricultural practices for each sampling date, $P<0.05$ (ANOVA with Tukey's post-hoc test).

biomass of the worms by working on the effect of organic enrichment in French vineyards. In the same way, Reinecke et al. [53] reported that organic treatments favoured earthworm proliferation.

In contrast, the total earthworm numbers and the proportion of juveniles in the reduced tillage inter-rows decreased dramatically over time compared to those under other agricultural practices or in the control, suggesting a disturbance in earthworm communities turnover. Moreover, the individual biomass was significantly lower in mechanical weeding, as already reported by Peigné et al. [54] and Paoletti et al. [55]. Mechanical weeding was found to be responsible for habitat disturbance, physical damage to earthworms, and disturbance in reproduction function among other things [15]. Investigating the effects of tillage on the earthworm Aporrectodea turgida, Eriksen-Hamel et al. [56] suggested that tillage-induced disturbance probably has a greater impact on earthworm populations in cool, humid agroecosystems than food availability.

None of these disruptions appeared in the grass-covered interrows, with the exception of spring 2009. Indeed, the latter vineyard plot was comparable to grassland. As reported by Vršič [57], the permanent grass cover in vineyards is responsible for a low nutrient loss and high humidity, which provides a better environment for earthworm growth.

Concerning densities and communities, juveniles of the anecic species A. nocturna [39] and Nicodrilus caliginosus meridionalis [12] were the most numerous in the Gaillac vineyard, as previously observed by Smith et al. [18] in other intensively managed agricultural systems. Overall, the anecics were abundant at neutral $\mathrm{pH}$, as reported in forest soils by Salmon [58], but agricultural practices were not found to be a good predictor of anecic biomass [59]. The anecic community was not clearly affected by changes in soil management practices in the vineyard, and has been previously reported to be relatively tolerant to agricultural activities [18]. The epi-anecics were the least well represented in the experimental area, as they are surface living, sensitive to environmental disturbances and sparse in cultivated soils [48]. The comparison of the relative abundance of the communities suggests that chemical weeding decreased the number of the epi-anecic species $L$. friendi in proportion to the other ecological categories. These poorly studied earthworms [60] are certainly more sensitive to chemicals.

Even if the tillage used for mechanical weeding in vineyards was superficial, involving non-inversion loosening of the topsoil down to a depth of $15 \mathrm{~cm}$, the diversity of earthworm communities could be impacted, as reported by previous studies $[15,37,61,62]$.
The relative abundance trends under mechanical weeding show that the proportion of endogeics and epi-anecics living in the first $15 \mathrm{~cm}$ of soil was lower than under the other practices or the controls. This was mainly attributed to superficial tillage effects, such as mechanical damage, burrow and habitat destruction, soil desiccation, deeper transport of organic matter, and predation risks, as described by Edwards and Bohlen [63] and Chan [64]. Anecic earthworms such as A. nocturna, Aporrectodea longa or Aporrectodea meridionalis are less exposed because of their vertical burrows and their ability to migrate quickly $[12,39]$. Finally, the grass-covered inter-rows had a proportionally similar distribution of earthworm categories as the controls. The grass-covering with high root-hair density encouraged earthworm development as in a natural ecosystem [65], and this was shown to be the least destructive practice in terms of ecological effects on worms.

\subsection{Impact of vineyard soil management on pesticide ecotoxicity for earthworms}

Enzyme activities were recorded over a six-month period on A. nocturna. Basal levels in controls change according to seasonal periods, suggesting a high sensitivity of biochemical biomarkers. This effect has been previously described by Arnaud et al. [66] and Laszczyca et al. [67], In addition, age, body size, metabolic rate and internal homeostasis could modify biomarker responses [20,64].

In our experimental vineyard conditions, the activation of CAT activity was registered in May when chemical and mechanical weeding had been used. This CAT activation was previously observed in microcosms after the short-term exposure of Aporrectodea caliginosa nocturna to pesticides [24] and E. fetida to atrazine [68]. In field conditions, Kiliç [29] reported that CAT activity in earthworms was significantly higher than the controls in various agricultural soils exposed to chemicals. At the beginning of the fungicide and copper/sulphur treatments (May), for these two soil management practices, reactive oxygen species (ROS) production occurred, which has already been observed in microcosm conditions three days after fungicide exposure [24]. In contrast, GST activity showed no significant variation compared to controls during May.

According to Brown et al. [21] and Lin et al. [69], two hypotheses can be proposed: (i) fungicides are not metabolised by the phase II system in which GST is implicated, or (ii) the GST activity may have been induced before, in the very early days of exposure, but stabilised during the test period.

Finally, in October, a few months after pesticide treatments, both activities were partially inhibited under chemical and mechanical weeding, in comparison to the controls. This inhibition could be due to a potential toxic stress caused by pesticides, which has been reported to cause cellular dysfunction or apoptosis $[21,24,70]$. Brown et al. [21] reported that metabolisation and antioxidant enzymes cannot cope with acute toxic stress and may be inhibited after a long-term exposure (cellular dysfunction or apoptosis) [70]. Chemical and mechanical weeding were the two plots in which A. nocturna was impacted, suggesting an increase in insecticide and fungicide bioavailability.

In this study, performed in vineyards, there were no ChE activity variations, regardless of the soil management practice applied and the sampling date. In contrast, Denoyelle et al. [30] showed a significant inhibition of cholinesterase activity under pesticide exposure working in orchard field experiments, with variations due to the different pest protection strategies. These differences in ChE inhibition could be explained by different factors, including the nature of the sprayed pesticides, the quantities applied, the period of pesticide spraying [41], the earthworm species [71] and the soil properties [7]. 
Using the same pesticide mixture (chlorpyrifos-ethyl and $\lambda$ cyhalothrin as insecticides and folpet, metalaxyl-M, fosetyl-Al and myclobutanil as fungicides) in controlled experiments, Schreck et al. [24] concluded that there was an inhibition of ChE activity in exposed earthworms. The limitations of the extrapolation of ecotoxicity results from laboratory conditions to field experiments was previously highlighted by Denoyelle et al. [30] and Laszczyca et al. [67]. However, numerous studies in microcosms are still performed to assess the impact of pollutants on earthworms [19-24] and only few investigations are carried out under field conditions [32].

Furthermore, even if the pesticides sprayed were neurotoxic, ChE activity was not significantly inhibited in this vineyard study. In field experiments rather than soil management practices, several basic phenomena such as pesticide transfer processes (leaching) or interference with various environmental parameters could mitigate earthworm biochemical responses [30,41,71] differently according to the enzymes studied.

\section{Conclusion and perspectives}

Soil management practices in vineyards have direct and indirect impacts on the ecology and physiology of earthworms. In this study, mechanical and chemical weeding caused negative effects on earthworm proliferation in the vineyards, including ecological communities, worm number and biomass, and they increased pollutant bioavailability, as suggested by changes in earthworm biotransformation processes. The grass-cover in the vine inter-rows seemed to be the more conservative solution from an environmental point of view.

This study has highlighted the importance of field experiments. To our knowledge, very few studies have combined ecological indicators and biochemical biomarkers to assess the environmental impacts of soil farming, especially in vineyards. Moreover, the majority of studies on earthworm biomarkers have been carried out under laboratory conditions, and only few studies have focused on native earthworm populations. Hence, there has been a growing interest in validating the effectiveness of biomarkers as an early warning of adverse ecological effects using field conditions.

Nevertheless, information is still lacking regarding the effect of other farming practices in vineyards, such as total grass cover, nitrogen fertilization and irrigation modes. As in the current studies, these practices could impact earthworms either directly by mechanical damage, such as burrow and habitat destruction, soil desiccation, deeper transport of organic matter and predation risks, or indirectly, by changing the fate of nutrients and overall pesticides in the vineyard soils. Therefore, further studies are needed and are currently in progress.

\section{Acknowledgements}

This study was funded by the Institut Français de la Vigne et du Vin and the Centre Universitaire de Formation et de Recherche of Albi, France. We thank the "Domaine Expérimental Viticole Tarnais" for their technical collaboration. We are grateful to Dr. Yvan Capowiez for his help in earthworm identification, and Sylvie Roussel and Cécile Fontange from Ondalys for performing PCA statistics.

\section{References}

[1] E. Concha-Grana, M.I. Turnes-Carou, S. Muniategui-Lorenzo, P. Lopez-Mahia, D. Prada-Rodriguez, E. Fernandez-Fernandez, Evaluation of $\mathrm{HCH}$ isomers and metabolites in soils, leachates, river water and sediments of a highly contaminated area, Chemosphere 64 (2006) 588-595.

[2] E. Gil, J. Llorens, A. Landers, J. Llop, L. Giralt, Field validation of Dosaviña, a decision support system to determine the optimal volume rate for pesticide application in vineyards, Eur. J. Agron. 35 (2011) 33-46.
[3] X. Louchart, M. Voltz, P. Andrieux, R. Moussa, Herbicide transport to surface waters at field and watershed scales in a Mediterranean vineyard area, J. Environ. Qual. 30 (2001) 982-991.

[4] J.G. Lacas, M. Voltz, V. Gouy, N. Carluer, J.J. Gril, Using grassed strips to limit pesticide transfer to surface water: a review, Agron. Sustain. Dev. 25 (2005) $253-266$.

[5] S.J. Fonte, T. Winsome, J. Six, Earthworm populations in relation to soil organic matter dynamics and management in California tomato cropping systems, Appl. Soil Ecol. 41 (2009) 206-214.

[6] J.W. Doran, M. Sarrantonio, M.A. Liebig, Soil health and sustainability, in: D.L. Sparks (Ed.), Advances in Agronomy, Academic Press, San Diego, CA, 1996 pp. $1-54$.

[7] C. Floch, Y. Capowiez, S. Criquet, Enzyme activities in apple orchard agroecosystems: how are they affected by management strategy and soil properties, Soil Biol. Biochem. 41 (2009) 61-68.

[8] R.A. Düring, T. Hoß, S. Gäth, Depth distribution and bioavailability of pollutants in long-term differently tilled soils, Soil Till. Res. 66 (2002) 183-195.

[9] P.F. Hendrix, B.R. Mueller, R.R. Bruce, G.W. Langdale, R.W. Parmelee, Abundance and distribution of earthworms in relation to landscape factors in the Georgia Piedmont, USA, Soil Biol. Biochem. 24 (1992) 1357-1361.

[10] P. Lavelle, I. Barois, A. Martin, Z. Zaidl, R. Schaefer, Management of earthworm populations in agroecosystems: a possible way to maintain soil quality? in: M. Clarholm, L. Bergström (Eds.), Ecology of Arable Land Kluwer Academic Publishers, Dordrecht, 1989, pp. 109-122.

[11] J. Römbke, S. Jänsch, W. Didden, The use of earthworms in ecological soil classification and assessment concepts, Ecotoxicol. Environ. Saf. 62 (2005) 249-265.

[12] M.B. Bouché, in: Lombriciens de France: Ecologie et Systématique, Institut national de la recherche scientifique, France, 1972, p. 671.

[13] R.W. Sims, B.M. Gerard, Earthworms, FSC Publications, London, 1999, 167.

[14] R.J. Haynes, C.S. Dominy, M.H. Graham, Effect of agricultural land use on soil organic matter status and the composition of earthworm communities in KwaZulu-Natal, South Africa, Agr. Ecosyst. Environ. 95 (2003) 453-464.

[15] G. Ernst, C. Emmerling, Impact of five different tillage types on soil organic carbon content and the density, biomass, and community composition of earthworms after a ten year period, Eur. J. Soil Biol. 45 (2009) 247-251.

[16] M. Langmaack, S. Schrader, U. Rapp-Bernhardt, K. Kotzke, Quantitative analysis of earthworm burrow systems with respect to biological soil-structure regeneration after soil compaction, Biol. Fertil. Soils 28 (1999) 219-229.

[17] C.A. Edwards, P.J. Bohlen, D.R. Linden, S. Subler, Earthworms in agroecosystems, in: P.F. Hendrix (Ed.), Earthworm Ecology and Biogeography in North America, Lewis Publishers, Boca Raton, FL, 1995, pp. 185-213.

[18] R.G. Smith, C.P. McSwiney, A.S. Grandy, P. Suwanwaree, R.M. Snider, G.P. Robertson, Diversity and abundance of earthworms across an agricultural land-use intensity gradient, Soil Till. Res. 100 (2008) 83-88.

[19] N. Gambi, A. Pasteris, E. Fabbri, Acetylcholinesterase activity in the earthworm (Eisenia andrei) at different conditions of carbaryl exposure, Comp. Biochem. Physiol. C 145 (2007) 678-685.

[20] S.A. Reinecke, A.J. Reinecke, Biomarker response and biomass change of earthworms exposed to chlorpyrifos in microcosms, Ecotoxicol. Environ. Saf. 66 (2007) 92-101.

[21] P.J. Brown, S.M. Long, D.J. Spurgeon, C. Svendsen, P.K. Hankard, Toxicological and biochemical responses of the earthworm Lumbricus rubellus to pyrene, a non-carcinogenic polycyclic aromatic hydrocarbon, Chemosphere 57 (2004) 1675-1681.

[22] N. Xiao, B. Jing, F. Ge, X. Liu, The fate of herbicide acetochlor and its toxicity to Eisenia fetida under laboratory conditions, Chemosphere 62 (2006) 1366-1373.

[23] D. Ribera, J.F. Narbonne, C. Arnaud, M. Saint-Denis, Biochemical responses of the earthworm Eisenia fetida andrei exposed to contaminated artificial soil, effects of carbaryl, Soil Biol. Biochem. 33 (2001) 1123-1130.

[24] E. Schreck, F. Geret, L. Gontier, M. Treilhou, Neurotoxic effect and metabolic responses induced by a mixture of six pesticides on the earthworm Aporrectodea caliginosa nocturna, Chemosphere 71 (2008) 1832-1839.

[25] A. Calisi, M.G. Lionetto, T. Schettino, Biomarker response in the earthworm Lumbricus terrestris exposed to chemical pollutants, Sci. Total Environ. 409 (2011) 4456-4464

[26] M. Saint-Denis, F. Labrot, J.F. Narbonne, D. Ribera, Glutathione, glutathione related enzymes and catalase activities in the worm Eisenia fetida, Arch. Environ. Contam. Toxicol. 35 (1998) 594-606.

[27] H. Eijsackers, P. Beneke, M. Maboeta, J.P.E. Louw, A.J. Reinecke, The implications of copper fungicide usage in vineyards for earthworm activity and resulting sustainable soil quality, Ecotoxicol. Environ. Saf. 62 (2005) 99-111.

[28] S.A. Reinecke, A.J. Reinecke, The impact of organophosphate pesticides in orchards on earthworms in the Western Cape, South Africa, Ecotoxicol. Environ. Saf. 66 (2007) 244-251.

[29] G.A. Kılıç, Histopathological and biochemical alterations of the earthworm (Lumbricus terrestris) as biomarker of soil pollution along Porsuk river Basin (Turkey), Chemosphere 83 (2011) 1175-1180.

[30] R. Denoyelle, M. Rault, C. Mazzia, O. Mascle, Y. Capowiez, Cholinesterase activity as a biomarker of pesticide exposure in Allolobophora chlorotica earthworms living in apple orchards under different management strategies, Environ. Toxicol. Chem. 26 (2007) 2644-2649. 
[31] B. Helling, S.A. Reinecke, A.J. Reinecke, Effects of the fungicide copper oxychloride on the growth and reproduction of Eisenia fetida (Oligochaeta), Ecotoxicol. Environ. Saf. 46 (2000) 108-116.

[32] J. Nahmani, M.E. Hodson, S. Black, A review of studies performed to assess metal uptake by earthworms, Environ. Pollut. 145 (2007) 402-424.

[33] ISSS Working Group RB, in: J.A. Deckers, F.O. Nachtergaele, O.C. Spaargaren (Eds.), International Society of Soil Science (ISSS), International Soil Reference and Information Centre (ISRIC) and Food and Agriculture Organisation of the United Nations (FAO), first ed., KULeuven Academic Press, Acco, Leuven, Belgium7, 1998.

[34] D. Gavalda, J.D. Scheiner, J.C. Revel, G. Merlina, M. Kaemmerer, E. Pinelli, M. Guiresse, Agronomic and environmental impacts of a single application of heat-dried sludge on an Alfisol, Sci. Total Environ. 343 (2005) 97-109.

[35] E. Serrano, E. Lauriac, E. Chantelot, Entretien des sols dans trois vignobles de Midi-Pyrénées: Résultats d'enquête et éléments de réflexion: Lutte contre les mauvaises herbes, Phytoma La défence des végétaux 544 (2001) 39-41.

[36] J.P. Curry, P. Doherty, G. Purvis, O. Schmidt, Relationships between earthworm populations and management intensity in cattle-grazed pastures in Ireland, Appl. Soil Ecol. 39 (2008) 58-64.

[37] C. Emmerling, Response of earthworm communities to different types of soil tillage, Appl. Soil Ecol. 17 (2001) 91-96.

[38] C. Pelosi, M. Bertrand, Y. Capowiez, H. Boizard, J. Roger-Estrade, Earthworm collection from agricultural fields: comparisons of selected expellants in presence/absence of hand-sorting, Eur. J. Soil Biol. 45 (2009) 176-183.

[39] M. Pérez-Losada, M. Ricoy, J.C. Marshall, J. Domínguez, Phylogenetic assessment of the earthworm Aporrectodea caliginosa species complex (Oligochaeta: Lumbricidae) based on mitochondrial and nuclear DNA sequences, Mol. Phylogenet. Evol. 52 (2009) 293-302.

[40] M.J.I. Briones, P. Morán, D. Posada, Are the sexual, somatic and genetic characters enough to solve nomenclatural problems in lumbricid taxonomy? Soil Biol. Biochem. 41 (2009) 2257-2271.

[41] M. Rault, C. Mazzia, Y. Capowiez, Tissue distribution and characterization of cholinesterase activity in six earthworm species, Comp. Biochem. Physiol. - Part B: Biochem. Mol. Biol. 147 (2007) 340-346.

[42] E. Schreck, F. Geret, L. Gontier, M. Treilhou, ChE, GST, CAT: evaluation of the efficiency of a combined buffer for protein extraction, Ecotoxicol. Environ. Saf. 72 (2009) 1609-1613.

[43] G. Ellman, K. Courtney, V. Andres, R.M. Featherstone, A new and rapid colorimetric determination of acetylcholinesterase activity, Biochem. Pharmacol. 7 (1961) 88-95

[44] W.H. Habig, M.J. Pabst, W.B. Jakoby, Glutathione-S-transferase: the first enzymatic step in mercapturic acid formation, J. Biol. Chem. 249 (1974) 7130-7139.

[45] M.M. Bradford, A rapid and sensitive method for the quantitation of microgram quantities of protein utilizing the principle of protein-dye binding, Anal. Biochem. 72 (1976) 248-254.

[46] L. Cognetti, Lombricidi dei Pirenei. Bollettino dei Musei di Zoologia, in: , Anatomia Comparata Torino, vol. 19, 1904, pp. 1-14.

[47] J. Valckx, M. Hermy, B. Muys, Indirect gradient analysis at subplot, plot and parcel level of prorated and non-prorated data of earthworm communities from agro-ecosystems in a temperate climate, in: Poster Communication at the XIV th International Colloquium on Soil Zoology and Ecology, Session 7 - Functional Groups and Valuation as Indicators of Soil Fauna (September, 2004).

[48] C. Pelosi, Modélisation de la dynamique d'une population de vers de terre Lumbricus terrestris au champ. Contribution à l'étude de l'impact de systèmes de culture sur les communautés lombriciennes. Thesis, Institut des Sciences et Industries du Vivant et de l'Environnement (Agro Paris Tech). (2008) p. 141.

[49] T.R. Knight, R.P. Dick, Differentiating microbial and stabilized $\beta$-glucosidase activity relative to soil quality, Soil Biol. Biochem. 36 (2004) 2089-2096.

[50] O.M. Christensen, J.G. Mather, Pesticide-induced surface migration by lumbricid earthworms in grass-land: life-stage and species differences, Ecotoxicol. Environ. Saf. 57 (2004) 89-99.
[51] M. Santos, Ecotoxicological Assessment of the Effects of Pesticide Application to Eisenia Andrei and Folsomia candida Using an Agricultural Soil Contaminated in the Field and in the Laboratory, in: Oral Presentation at SETAC Europe 18 th Annual Meeting, Warsaw, Poland (May 2008).

[52] G. Pérès, D. Cluzeau, P. Curmi, V. Hallaire, Earthworm activity and soil structure changes due to organic enrichments in vineyard systems, Biol. Fert. Soils 27 (1998) 417-424.

[53] A.J. Reinecke, R.M.C. Albertus, S.A. Reinecke, O. Larink, The effects of organic and conventional management practices on feeding activity of soil organisms in vineyards, Afric. Zool. 43 (2008) 66-74.

[54] J. Peigné, M. Cannavaciuolo, Y. Gautronneau, A. Aveline, J.L. Giteau, D. Cluzeau, Earthworm populations under different tillage systems in organic farming, Soil Till. Res. 104 (2009) 207-214.

[55] M.G. Paoletti, D. Sommaggio, M.R. Favretto, G. Petruzzelli, B. Pezzarossa, M. Barbafieri, Earthworms as useful bioindicators of agroecosystem sustainability in orchards and vineyards with different inputs, Appl. Soil Ecol. 10 (1998) 137-150.

[56] N.S. Eriksen-Hamel, A.B. Speratti, J.K. Whalen, A. Légère, C.A. Madramootoo, Earthworm populations and growth rates related to long-term crop residue and tillage management, Soil Till. Res. 104 (2009) 311-316.

[57] S. Vršič, Soil erosion and earthworm population responses to soil management systems in steep-slope vineyards, Plant Soil Environ. 57 (2011) $258-263$.

[58] S. Salmon, Earthworm excreta (mucus and urine) affect the distribution of springtails in forest soils, Biol. Fertil. Soils 34 (2001) 304-310.

[59] M. Debeljak, J. Cortet, D. Demsar, P.H. Krogh, S. Dzeroski, Hierarchical classification of environment factors and agricultural practices affecting soil fauna under cropping systems using Bt maize, Pedobiologia 51 (2007) 229-238.

[60] K.R. Butt, M.J.I. Briones, Life cycle studies of the earthworm Lumbricus friendi (Cognetti, 1904), Pedobiologia 54S (2011) S27-S29.

[61] G.J. House, Comparison of soil arthropods and earthworms from conventional and no-tillage agro-ecosystems, Soil Till. Res. 5 (1985) 351-360.

[62] G.S. Francis, T.L. Knight, Long-term effects of conventional and no-tillage on selected soil properties and crop yields in Canterbury, NewZealand, Soil Till. Res. 26 (1993) 193-210.

[63] C.A. Edwards, P.J. Bohlen, Biology and Ecology of Earthworms, third ed., Chapman \& Hall, London, United Kingdom, 1996, p. 426.

[64] K.Y. Chan, An overview of some tillage impacts on earthworm population abundance and diversity - implications for functionning in soils, Soil Till. Res. 57 (2001) 179-191.

[65] O. Butenschoen, S. Marhan, S. Scheu, Response of soil microorganisms and endogeic earthworms to cutting of grassland plants in a laboratory experiment, Appl. Soil Ecol. 38 (2008) 152-160.

[66] C. Arnaud, M. Saint-Denis, J.F. Narbonne, P. Soler, D. Ribera, Influences of different standardised test methods on biochemical responses in the earthworm Eisenia fetida andrei, Soil Biol. Biochem. 32 (2000) 67-73.

[67] P. Laszczyca, M. Augustyniak, A. Babczynska, K. Bednarska, K. Alina, P. Migula, G. Wilczek, I. Witas, Profiles of enzymatic activity in earthworms from zinc, lead and cadmium polluted areas near Olkusz (Poland), Environ. Int. 30 (2004) 901-910.

[68] Y. Song, L.S. Zhu, J. Wang, J.H. Wang, W. Liu, H. Xie, DNA damage and effects on antioxidative enzymes in earthworm (Eisenia foetida) induced by atrazine, Soil Biol. Biochem. 41 (2009) 905-909.

[69] D. Lin, Q. Zhou, X. Xie, Y. Liu, Potential biochemical and genetic toxicity of triclosan as an emerging pollutant on earthworms (Eisenia fetida), Chemosphere 81 (2010) 1328-1333.

[70] L. Sweet, D. Passino-Reader, P. Meier, G. Omann, Xenobiotic induced apoptosis: significance and potential application as a general biomarker of response, Biomarkers 4 (1999) 237-253.

[71] M. Rault, B. Collange, C. Mazzia, Y. Capowiez, Dynamics of acetylcholinesterase activity recovery in two earthworm species following exposure to ethyl-parathion, Soil Biol. Biochem. 40 (2008) 3086-3091. 